\title{
Major Salivary Gland Cancer Pathologic Primary Tumor TNM Finding v8
}

National Cancer Institute

\section{Source}

National Cancer Institute. Major Salivary Gland Cancer Pathologic Primary Tumor TNM

Finding v8. NCI Thesaurus. Code C132743.

A pathologic finding about one or more characteristics of major salivary gland cancer, following the rules of the TNM AJCC v8 classification system as they pertain to staging of the primary tumor. 